\title{
Antibiotic Resistance of Vibrio anguillarum, in Relation to Serovar and Plasmid Contents
}

\author{
By K. Pedersen, T. Tiainen and J. L. Larsen
}

Department of Veterinary Microbiology, Laboratory of Fish Diseases, The Royal Veterinary and Agricultural University, Frederiksberg, Denmark.

\begin{abstract}
Pedersen, K., T. Tiainen and J.L. Larsen: Antibiotic resistance of Vibrio anguillarum, in relation to serovar and plasmid contents. Acta vet. scand. 1995, 36, 55-64. - A total of 520 Vibrio anguillarum strains, isolated from fish and the environment, were tested for their sensitivity to 20 different antibiotics. Most isolates were of European origin. The results were compared with data on the O-serogroup and plasmid contents. All strains were sensitive to neomycin, spectinomycin, nitrofurantoin, flumequine and oxolinic acid, while most strains were sensitive to streptomycin, oxytetracycline, chloramphenicol, sulphonamides, trimethoprim, sulphonamides with trimethoprim, nalidixan, rifampicin, novobiocin and O/129. A major part of the strains were resistant to the macrolides, spiramycin and lincomycin. For ampicillin, cephalothin, and colistin marked differences were recorded with respect to O-serogroup. Most O1 strains were resistant to colistin and sensitive to ampicillin and cephalothin, while most $\mathrm{O} 2$ strains were sensitive to colistin but resistant to ampicillin and cephalothin. Some antibiotic resistant strains carried plasmids but no conjugation experiments were carried out to detect possible $\mathrm{R}$ factors.
\end{abstract}

serogroup.

\section{Introduction}

Various antibiotics are used for treatment of bacterial infections - including vibriosis - in fish. The efficiency of the treatment depends on the sensitivity of the causative agent to the chosen drug. Use of a wrong antibiotic substance will result in excess expences for medication, loss of fish due to lack of effect of treatment, and poor quality of survivors. Recently, it was suggested that the immunomodulating effect of some antibiotics might impair the effect of therapy and the recovery of diseased fish (van der Heijden et al. 1992). Furthermore, inappropriate use of antibiotics is likely to cause unnecessary impact on the environment and the emergence of drug resistant bacteria. Hansen et al. (1992) showed that oxytetracycline and oxolinic acid were able to persist in sediment for several months and give rise to a significant increase in resistance to these compounds among bacteria present in the sediment. Furazolidone, in contrast, was completely degraded within a few days. This high environmental stability of tetracycline and oxolinic acid was confirmed by $\mathrm{Sa}$ muelsen (1992). In another study, oxolinic acid was detected in the wild fauna (fish, crustaceans, and molluscs) in the environment in the vicinity of aquaculture facilities during and after treatment with this drug (Lunestad 1992). Also the risk of having residues of antibiotic substances in fish meat for human consumption should be considered (Alderman \& Michel 1992), and requirement of standard- 
ization and safety of drugs used in aquaculture for protection of the environment and humans has recently been emphasized (Schlotfeldt 1992).

Resistance to commonly used antibiotics has been reported for several marine and fish pathogenic bacteria (Aoki 1992). Aoki et al. (1980) demonstrated that the principal drug resistant bacteria isolated from the intestinal tract of cultured ayu (Plecoglossus altivelis) were Aeromonas hydrophila and Vibrio anguillarum. Antibiotic resistance among V. anguillarum was first reported to occur in 1973 in Japan (Aoki et al. 1974). These authors stated that all strains examined by them before 1972 were sensitive to all drugs tested but most likely due to an extensive use of antibiotics in fish culturing, resistant $V$. anguillarum strains had emerged and quickly spread. Since then widespread resistance to one or - more commonly - several antibiotics in various combinations has been described in this bacterial species (Aoki 1992, Aoki et al. 1981, 1985, Zhao et al. 1992). Apparently, in most other countries, $V$. anguillarum isolates are still sensitive to most commonly used antibiotics.

Resistance to antibiotics can be plasmid or chromosomally encoded. Plasmids have been demonstrated in several marine (Aoki et al. 1980, Davidson \& Oliver 1986, Sizemore \& Colwell 1977) and fish pathogenic bacteria (Aoki 1992, Aoki et al. 1980, Sørum et al. 1988, Sørum et al. 1993, Toranzo et al. 1983a,b). Toranzo et al. (1991) found no correlation between antibiotic resistance and plasmid content of Spanish Aeromonas salmonicida isolates. In contrast, Hedges et al. (1985) demonstrated 2 plasmids in $A$. salmonicida strains from Japan and United Kingdom, encoding resistance to streptomycin, chloramphenicol, and sulphonamides and to streptomycin, tetracycline, and chloramphenicol, respectively.
Inglis et al. (1993) described transferable $\mathrm{R}$ plasmids in tetracycline-resistant $A$. salmonicida strains from Atlantic salmon (Salmo salar) in Scotland, and from Norway, Sandaa \& Enger (1993) reported the quick spread of a plasmid, pRAS1, approximately $45 \mathrm{~kb}$, encoding multi-resistance among $A$. salmonicida. In addition, plasmid mediated drug resistance has been described in fish pathogens such as $A$. hydrophila, Edwardsiella tarda, and Vibrio species (Aoki 1992), including the human pathogen, Vibrio cholerae (Hedges et al. 1977). In $V$. anguillarum, the presence of a 67 $\mathrm{kb}$ virulence plasmid among most fish pathogenic serovar $\mathrm{O} 1$ isolates is well documented (Crosa et al. 1977, Larsen 1990, Larsen \& Olsen 1991) However, no antibiotic resistance factors have so far been associated with this plasmid. $\mathrm{R}$ plasmids in $V$. anguillarum seem to be of high molecular weight. Aoki et al. (1985) estimated the molecular weight to $105 \mathrm{MDa}$, while Mitoma et al. (1984) found R plasmids between 80 and $120 \mathrm{MDa}$ and belonging to at least 4 groups of homology, depending on time of isolation and their geographical origin. Aoki et al. (1980) detected R plasmids in all drug resistant $V$. anguillarum strains they examined.

In the present study we examined the sensitivity of $520 \mathrm{~V}$. anguillarum strains to 20 different antimicrobial substances and related these results to serotype and plasmid content.

\section{Materials and methods}

Bacterial strains and culture conditions

A total of 520 Vibrio anguillarum isolates were used in the experiments. The strains were isolated in our own laboratory or received from various other laboratories. Most strains had been isolated in Europe. They were kept at $-80^{\circ} \mathrm{C}$ in broth, added $25-50 \%$ sterile glycerol, until use. The strains were cul- 
tured on blood agar plates (blood agar base, Gibco BRL, added 5\% sterile citrate stabilized calf blood), incubated at $20^{\circ} \mathrm{C}$ for $48 \mathrm{~h}$.

\section{Antibiotic sensitivity testing}

Sensitivity to 20 different antibiotics and chemotherapeutics (Table 1) was examined by the agar diffusion method (Neo-Sensitabs, Rosco Diagnostica, Taastrup, Denmark), carried out according to the instructions of the manufacturer (Casals \& Pringler 1991). Cultures in LB (Luria-Bertani) broth (LB broth base, Gibco BRL) incubated overnight at $20^{\circ} \mathrm{C}$ were diluted 1:2000 and plated on Mueller-Hinton agar (Difco) whereafter antibiotic containing discs were placed on the agar surface. Inhibition zones were read after $48 \mathrm{~h}$ incubation at $20^{\circ} \mathrm{C}$. MIC values were determined by culturing bacteria on MuellerHinton agar containing two-fold dilutions of the antibiotic substance.

\section{Plasmid profiling}

Plasmid DNA was extracted by the method described by Kado \& Liu (1981). Isolated plasmids were separated by electrophoresis in $0.8 \%$ agarose (SeaKem GTG, FMC BioProducts, Rockland, ME, USA) gels in TAE buffer (Tris $40 \mathrm{mM}$, sodium acetate $5 \mathrm{mM}$, ethylenediaminetetraacetate (EDTA) $1 \mathrm{mM}$ ) $\mathrm{pH}$ 7.8. Molecular weight of plasmids was determined using plasmids of Eschericha coli 39R861 and V517 (Macrina et al. 1978, Threlfall et al. 1986) as size markers. Migration lengths of plasmids from the reference strains versus plasmid sizes were blotted in double logarithmic diagrams, and the molecular weight of plasmids from the $V$. anguillarum strains was read from the standard curve.

\section{O-serotyping}

O-serotyping of Vibrio anguillarum was carried out by the slide agglutination test as pre- viously described (Sørensen \& Larsen 1986, Larsen et al. 1994).

\section{Results}

The results - total and distributed into O-serogroups - are summarized in Table 1. All 520 strains were sensitive to neomycin, spectinomycin, nitrofurantoin, flumequine, and oxolinic acid.

A few strains showed resistance or intermediary sensitivity to streptomycin, oxytetracycline, chloramphenicol, sulphonamides, trimethoprim, sulphonamides with trimethoprim, nalidixan, rifampicin or novobiocin. Additionally, 3 strains were resistant to $\mathrm{O} / 129$, $10 \mu \mathrm{g}, 1$ strain additionally being resistant to $\mathrm{O} / 129,150 \mu \mathrm{g}$. The strains resistant or intermediary sensitive to these antibiotics are listed in Table 2 together with information about their serotype and plasmid contents. Some of the strains shown in Table 2 carried plasmids varying in size from $4.4 \mathrm{~kb}$ to approximately $160 \mathrm{~kb}$. A single strain showed resistance to streptomycin, sulphonamides, trimethoprim, sulphonamides with trimethoprim, O/129 and additionally to cephalothin, spiramycin and lincomycin. However, this multiresistant strain carried no plasmids.

Several strains showed resistance to ampicillin, cephalothin or colistin or combination of these 3 drugs. For ampicillin, cephalothin and colistin marked differences were noticed between serogroups (Table 1). Serogroup O1 and $\mathrm{O} 3$ isolates tended to be sensitive to ampicillin and cephalothin but resistant to colistin, while serogroup $\mathrm{O} 2$ and other serogroups were mostly resistant to ampicillin and sensitive to colistin. A large proportion of the $\mathrm{O} 2$ strains were resistant to cephalothin. The sizes of inhibition zones for the serogroup $\mathrm{O} 1$ and $\mathrm{O} 2$ strains with respect to ampicillin and colistin are shown in Fig. 1 and 2. The distri- 
Table 1. Suspectibility of Vibrio anguillarum to various antibiotics. Results are recorded for each O-serogroup together with the total results. $\mathrm{N}=520$.

\begin{tabular}{|c|c|c|c|c|c|c|c|c|c|c|c|c|c|c|c|c|c|c|}
\hline \multirow[t]{2}{*}{ Antibiotic } & \multicolumn{3}{|c|}{$\begin{array}{c}\text { Serotype O1 } \\
\mathrm{n}=219 \\
\end{array}$} & \multicolumn{3}{|c|}{$\begin{array}{c}\text { Serotype } \mathrm{O} 2 \\
\mathrm{n}=154 \\
\end{array}$} & \multicolumn{3}{|c|}{$\begin{array}{c}\text { Serotype O3 } \\
\mathrm{n}=29\end{array}$} & \multicolumn{3}{|c|}{$\begin{array}{c}\text { Serotype O4 } \\
\mathrm{n}=10\end{array}$} & \multicolumn{3}{|c|}{$\begin{array}{c}\text { Serotype O5 } \\
\mathrm{n}=11\end{array}$} & \multicolumn{3}{|c|}{$\begin{array}{c}\text { Serotype O6 } \\
n=6\end{array}$} \\
\hline & $\mathrm{S}^{\mathrm{a})}$ & I $^{\text {a) }}$ & $\mathbf{R}^{\mathbf{a})}$ & $S$ & I & $\mathbf{R}$ & $\mathrm{S}$ & I & $\mathrm{R}$ & $S$ & I & $\mathbf{R}$ & $\mathrm{s}$ & I & $\mathbf{R}$ & $\mathrm{S}$ & I & $\mathbf{R}$ \\
\hline Ampicillin & 158 & 51 & 10 & 20 & 35 & 99 & 17 & 8 & 4 & 3 & 2 & 5 & 1 & 2 & 8 & 1 & 2 & 3 \\
\hline Cephalothin & 217 & 2 & 0 & 64 & 7 & 83 & 27 & 2 & 0 & 6 & 0 & 4 & 8 & 2 & . & 3 & 0 & 3 \\
\hline Streptomycin & 219 & 0 & 0 & 153 & 0 & 1 & 29 & 0 & 0 & 10 & 0 & 0 & 11 & 0 & 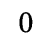 & 6 & 0 & 0 \\
\hline Neomycin & 219 & 0 & 0 & 154 & 0 & 0 & 29 & 0 & 0 & 10 & 0 & 0 & 11 & 0 & 0 & 6 & 0 & 0 \\
\hline Spectinomycin & 219 & 0 & 0 & 154 & 0 & 0 & 29 & 0 & 0 & 10 & 0 & 0 & 11 & 0 & 0 & 6 & 0 & 0 \\
\hline Oxytetracycline & 218 & 0 & 1 & 154 & 0 & 0 & 29 & 0 & 0 & 10 & 0 & 0 & 11 & 0 & 0 & 6 & 0 & 0 \\
\hline Chloramphenicol & 219 & 0 & 0 & 153 & 0 & 1 & 29 & 0 & 0 & 10 & 0 & 0 & 11 & 0 & 0 & 6 & 0 & 0 \\
\hline Spiramycin & 9 & 77 & 133 & 47 & 59 & 48 & 2 & 10 & 17 & 0 & 3 & 7 & 0 & 2 & 9 & 0 & 0 & 0 \\
\hline Lincomycin & 2 & 36 & 181 & 4 & 8 & 142 & 0 & 10 & 19 & 0 & 0 & 10 & 0 & 0 & 11 & 0 & 0 & 0 \\
\hline Colistin & 32 & 15 & 172 & 151 & 1 & 2 & 11 & 1 & 17 & 9 & 1 & 0 & 9 & 0 & 2 & 6 & 0 & 0 \\
\hline Sulfonamides & 219 & 0 & 0 & 151 & 1 & 2 & 29 & 0 & 0 & 10 & 0 & 0 & 11 & 0 & 0 & 6 & 0 & 0 \\
\hline Trimethoprim & 219 & 0 & 0 & 153 & 0 & 1 & 28 & 1 & 0 & 10 & 0 & 0 & 11 & 0 & 0 & 6 & 0 & 0 \\
\hline Sulfa + TMP & 219 & 0 & 0 & 153 & 0 & 1 & 29 & 0 & 0 & 10 & 0 & 0 & 11 & 0 & 0 & 6 & 0 & 0 \\
\hline Nitrofurantoin & 219 & 0 & 0 & 154 & 0 & 0 & 29 & 0 & 0 & 10 & 0 & 0 & 11 & 0 & 0 & 6 & 0 & 0 \\
\hline Flumequine & 219 & 0 & 0 & 154 & 0 & 0 & 29 & 0 & 0 & 10 & 0 & 0 & 11 & 0 & 0 & 6 & 0 & 0 \\
\hline Oxolinic acid & 219 & 0 & 0 & 154 & 0 & 0 & 29 & 0 & 0 & 10 & 0 & 0 & 11 & 0 & 0 & 6 & 0 & 0 \\
\hline Nalidixan & 218 & 1 & 0 & 154 & 0 & 0 & 29 & 0 & 0 & 10 & 0 & 0 & 11 & 0 & 0 & 6 & 0 & 0 \\
\hline Rifampicin & 218 & 1 & 0 & 154 & 0 & 0 & 27 & 2 & 0 & 10 & 0 & 0 & 11 & 0 & 0 & 6 & 0 & 0 \\
\hline Novobiocin & 219 & 0 & 0 & 154 & 0 & 0 & 25 & 2 & 2 & 10 & 0 & 0 & 10 & 0 & 1 & 6 & 0 & 0 \\
\hline $\mathrm{O} / 12910 \mu \mathrm{g}$ & 219 & 0 & 0 & 153 & 0 & 1 & 29 & 0 & 0 & 10 & 0 & 0 & 9 & 0 & 2 & 6 & 0 & 0 \\
\hline $\mathrm{O} / 129150 \mu \mathrm{g}$ & 219 & 0 & 0 & 153 & 0 & 1 & 29 & 0 & 0 & 10 & 0 & 0 & 11 & 0 & 0 & 6 & 0 & 0 \\
\hline
\end{tabular}

butions of the 2 serogroups were very different from each other.

While most antibiotics caused well-defined inhibition zones surrounding the discs, spiramycin and to some extent lincomycin caused somewhat diffuse inhibition zones that could be interpreted only with some difficulty. It was therefore decided to determine MIC values for spiramycin on 20 arbitrarily selected strains. One strain had a MIC value of 16 $\mu \mathrm{g} / \mathrm{ml}, 1$ strain 32,4 strains 64 , and 14 strains $128 \mu \mathrm{g} / \mathrm{ml}$. Most strains were therefore considered resistant in accordance with the results of the disc diffusion experiments. In addition, 15 strains were tested for sensitivity to a third macrolide antibiotic, erythromycin. All these strains were resistant to spiramycin but sensitive to erythromycin.

\section{Discussion}

Antibiotic resistance among $V$. anguillarum has mainly been reported from Japan, where the problem has increased. Outside Japan, it has only been described occasionally, but studies on large numbers of strains and comparison of results with serotypes have not been conducted on European isolates. In a recent study, Myhr et al. (1991) found all isolates from Norway susceptible to sulphonamides with trimethoprim, nitrofurazolidone, oxytetracycline, oxolinic acid, flumequine, and enrofloxacin. Some of these antibiotics are commonly used in Norwegian aquaculture. However, this study comprised only $19 \mathrm{~V}$. anguillarum isolates and 39 Vibrio anguillarum-like strains. 
Table 1 (continued).

\begin{tabular}{|c|c|c|c|c|c|c|c|c|c|c|c|c|c|c|c|c|c|c|}
\hline \multirow[t]{2}{*}{ Antibiotic } & \multicolumn{3}{|c|}{$\begin{array}{c}\text { Serotype } 07 \\
n=5\end{array}$} & \multicolumn{3}{|c|}{$\begin{array}{c}\text { Serotype } 08 \\
n=5\end{array}$} & \multicolumn{3}{|c|}{$\begin{array}{c}\text { Serotype O9 } \\
\mathrm{n}=3\end{array}$} & \multicolumn{3}{|c|}{$\begin{array}{c}\text { Serotype } 010 \\
\mathrm{n}=1\end{array}$} & \multicolumn{3}{|c|}{$\begin{array}{c}\text { Non O1-O10 } \\
\mathrm{n}=77\end{array}$} & \multicolumn{3}{|c|}{$\begin{array}{c}\text { Total } \\
\mathrm{n}=520\end{array}$} \\
\hline & $\mathrm{s}$ & I & $\mathbf{R}$ & $\mathrm{S}$ & I & $\mathbf{R}$ & $\mathrm{s}$ & I & $\mathbf{R}$ & $\mathrm{s}$ & I & $\mathbf{R}$ & $\mathrm{s}$ & I & $\mathbf{R}$ & $\mathrm{S}$ & I & $\mathbf{R}$ \\
\hline Ampicillin & 0 & 2 & 3 & 1 & 1 & 3 & 2 & 0 & 1 & 0 & 0 & 1 & 27 & 13 & 37 & 230 & 116 & 174 \\
\hline Cephalothin & 2 & 0 & 3 & 3 & 1 & 1 & 3 & 0 & 0 & 0 & 0 & 1 & 65 & 1 & 11 & 398 & 15 & 107 \\
\hline Streptomycin & 4 & 0 & 1 & 5 & 0 & 0 & 3 & 0 & 0 & 1 & 0 & 0 & 75 & 0 & 2 & 516 & 0 & 4 \\
\hline Neomycin & 5 & 0 & 0 & 5 & 0 & 0 & 3 & 0 & 0 & 1 & 0 & 0 & 77 & 0 & 0 & 520 & 0 & 0 \\
\hline Spectinomycin & 5 & 0 & 0 & 5 & 0 & 0 & 3 & 0 & 0 & 1 & 0 & 0 & 77 & 0 & 0 & 520 & 0 & 0 \\
\hline Oxytetracycline & 5 & 0 & 0 & 5 & 0 & 0 & 3 & 0 & 0 & 1 & 0 & 0 & 72 & 4 & 1 & 514 & 4 & 2 \\
\hline Chloramphenicol & 5 & 0 & 0 & 5 & 0 & 0 & 3 & 0 & 0 & 1 & 0 & 0 & 77 & 0 & 0 & 519 & 0 & 1 \\
\hline Spiramycin & 1 & 1 & 3 & 0 & 1 & 4 & 1 & 0 & 2 & 0 & 0 & 1 & 8 & 17 & 52 & 68 & 170 & 282 \\
\hline Lincomycin & 1 & 1 & 3 & 0 & 0 & 5 & 0 & 1 & 2 & 0 & 0 & 1 & 3 & 8 & 66 & 10 & 64 & 446 \\
\hline Colistin & 5 & 0 & 0 & 4 & 0 & 1 & 2 & 0 & 1 & 1 & 0 & 0 & 72 & 0 & 5 & 302 & 18 & 200 \\
\hline Sulfonamides & 5 & 0 & 0 & 5 & 0 & 0 & 3 & 0 & 0 & 1 & 0 & 0 & 74 & 0 & 3 & 513 & 1 & 6 \\
\hline Trimethoprim & 5 & 0 & 0 & 5 & 0 & 0 & 3 & 0 & 0 & 1 & 0 & 0 & 77 & 0 & 0 & 518 & 1 & 1 \\
\hline Sulfa + TMP & 5 & 0 & 0 & 5 & 0 & 0 & 3 & 0 & 0 & 1 & 0 & 0 & 77 & 0 & 0 & 519 & 0 & 1 \\
\hline Nitrofurantoin & 5 & 0 & 0 & 5 & 0 & 0 & 3 & 0 & 0 & 1 & 0 & 0 & 77 & 0 & 0 & 520 & 0 & 0 \\
\hline Flumequine & 5 & 0 & 0 & 5 & 0 & 0 & 3 & 0 & 0 & 1 & 0 & 0 & 77 & 0 & 0 & 520 & 0 & 0 \\
\hline Oxolinic acid & 5 & 0 & 0 & 5 & 0 & 0 & 3 & 0 & 0 & 1 & 0 & 0 & 77 & 0 & 0 & 520 & 0 & 0 \\
\hline Nalidixan & 5 & 0 & 0 & 5 & 0 & 0 & 3 & 0 & 0 & 1 & 0 & 0 & 77 & 0 & 0 & 519 & 1 & 0 \\
\hline Rifampicin & 5 & 0 & 0 & 5 & 0 & 0 & 3 & 0 & 0 & 1 & 0 & 0 & 77 & 0 & 0 & 517 & 3 & 0 \\
\hline Novobiocin & 5 & 0 & 0 & 5 & 0 & 0 & 3 & 0 & 0 & 1 & 0 & 0 & 73 & 0 & 4 & 511 & 2 & 7 \\
\hline $\mathrm{O} / 12910 \mu \mathrm{g}$ & 5 & 0 & 0 & 5 & 0 & 0 & 3 & 0 & 0 & 1 & 0 & 0 & 77 & 0 & 0 & 517 & 0 & 3 \\
\hline $\mathrm{O} / 129150 \mu \mathrm{g}$ & 5 & 0 & 0 & 5 & 0 & 0 & 3 & 0 & 0 & 1 & 0 & 0 & 77 & 0 & 0 & 519 & 0 & 1 \\
\hline
\end{tabular}

a) S: sensitive, I: intermediary, R: resistent.

Tanaka et al. (1993) found a seasonal variation: Drug resistant $V$. anguillarum were most frequently isolated during the period from April until July. In the present study we had only sparce information about the time of isolation for most strains.

Tanaka et al. (1993) also reported that incidence of drug resistance was higher in serotype A than in serotype $C$ isolates. Serotypes $\mathrm{A}$ and $\mathrm{C}$ in the Japanese serotyping system correspond to serotypes 02 and 01 , respectively, in the European system (Larsen et al. 1994). In a study of Spanish $V$. anguillarum isolates (Toranzo et al. 1987) all strains were highly resistant to ampicillin. One of the strains in that study belonged to serogroup $\mathrm{O} 2$ while the rest were O1. In the present study we recorded marked differences in susceptibility patterns for ampicillin, cephalothin and colistin among serogroups. The distribution of the inhibition zone diameters for serogroup $\mathrm{O} 1$ and $\mathrm{O} 2$ were shown to be very different from each other concerning ampicillin and colistin. To the authors' knowledge, such differences have not previously been described. Resistance to these antibiotics did not correlate with presence or absence of plasmids, and are therefore supposed to be chromosomally encoded. These 3 antibiotics all affect the peptidoglycan layer or the outer membrane of the cell envelope, while the other antibiotics tested have other mechanisms of action. The differences noticed between serogroups may therefore reflect differences in the composition or structure of the cell envelope between 
Table 2. List of strains showing resistance or intermediary sensitivity to various antibiotics together with their serotype and plasmid content. Resistance to ampicillin, cephalothin, spiramycin, lincomycin, and colistin is not included.

\begin{tabular}{rlcl}
\hline & $\begin{array}{l}\text { Resistance or intermediary } \\
\text { sensitivity to }\end{array}$ & Serotype & $\begin{array}{l}\text { Plasmid } \\
\text { content }\end{array}$ \\
\hline 1 & streptomycin & $\mathrm{O} 7$ & empty \\
2 & tetracycline & $\mathrm{O} 1$ & $67 \mathrm{~kb}$ \\
3 & & $\mathrm{NT}$ & $30+36+48 \mathrm{~kb}$ \\
4 & & $\mathrm{NT}$ & $160 \mathrm{~kb}$ \\
5 & sulphonamides & $\mathrm{O} 1$ & $67 \mathrm{~kb}+50 \mathrm{~kb}$ \\
6 & & $\mathrm{O} 2$ & empty \\
7 & & $\mathrm{O} 2$ & $4.2 \mathrm{~kb}$ \\
8 & trimethoprim & $\mathrm{O} 3$ & empty \\
9 & nalidixan & $\mathrm{O} 1$ & $67 \mathrm{~kb}$ \\
10 & rifampicin & $\mathrm{O} 1$ & empty \\
11 & novobiocin & $\mathrm{O} 3$ & empty \\
12 & & $\mathrm{O} 3$ & empty \\
13 & & $\mathrm{O} 5$ & empty \\
14 & & $\mathrm{NT}$ & empty \\
15 & & $\mathrm{NT}$ & empty \\
16 & & $\mathrm{NT}$ & $88 \mathrm{~kb}$ \\
17 & & $\mathrm{NT}$ & $88 \mathrm{~kb}$ \\
18 & O/129, 10 $\mu \mathrm{g}$ & $\mathrm{O} 5$ & empty \\
19 & & $\mathrm{O} 5$ & empty \\
20 & tetracycline, sulphonamides & $\mathrm{NT}$ & $4.4 \mathrm{~kb}$ \\
21 & novobiocin, rifampicin & $\mathrm{O} 3$ & empty \\
22 & & $\mathrm{O} 3$ & empty \\
23 & streptomycin, tetracycline, sulphonamides & $\mathrm{NT}$ & empty \\
24 & & $\mathrm{NT}$ & $4.4 \mathrm{~kb}$ \\
25 & streptomycin, chloramphenicol, sulphonamides, & $\mathrm{O} 2$ & empty \\
& trimethoprim, sulphonamides with trimethoprim, & & \\
& O/129 $10 \mu \mathrm{g}$, O/129 150 $\mu \mathrm{g}$. & & \\
\hline & & & \\
\hline
\end{tabular}

serogroups, but at present this is completely unknown. Recently, a selective and indicative medium for the isolation of $V$. anguillarum was described (Alsina et al. 1994). This medium contains ampicillin for selective growth of $V$. anguillarum. Based on the present results we suggest that when using selective media containing antibiotics, it should be considered that certain serogroups may be suppressed giving rise to erroneous conclusions concerning epidemiology and prevalence.
Aoki et al. $(1974,1980)$ reported that drug resistance markers present in R plasmids of $V$. anguillarum from ayu were in most cases sulphonamides, streptomycin, chloramphenicol, and tetracycline but occasionally also nalidixic acid or nitrofurans, while Zhao et al. (1992) demonstrated R plasmids encoding resistance to 7-9 different antibiotics. Aoki et al. (1985) found multiple resistance to various combinations of ampicillin, chloramphenicol, tetracycline, streptomycin, colistin, nalidixic acid, furazolidone, sulphonamides, and trimethoprim. In that study, only 2 out of 139 


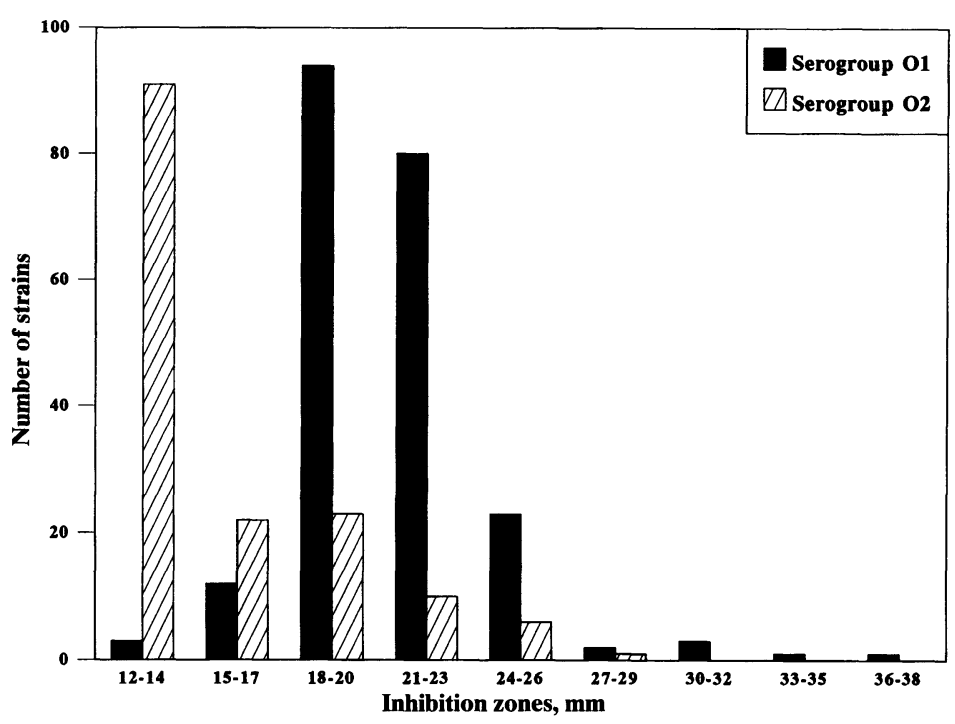

Figure 1. Inhibition zone diameters of Vibrio anguillarum serogroup $\mathrm{O} 1$ and $\mathrm{O} 2$ for ampicillin.

V. anguillarum strains were sensitive to all drugs tested while the remaining 137 strains were resistant to $1-8$ drugs. $R$ plasmids were detected in 30 of the 137 resistant strains. Zhao et al. (1992) found R plasmids in 21 out of 114 strains. Most of the strains were resistant to ampicillin, nalidixic acid, and furazolidone but they were unable to transfer resistance to these drugs to $E$. coli and therefore suggested that these resistance markers were chromosomally encoded. In contrast, Aoki et al. (1984) demonstrated ampicillin as well as trimethoprim resistance markers on $\mathbf{R}$ plasmids in 1980.

Muroga et al. (1979) reported a close connection between resistance of $V$. anguillarum to O/129 and to sulphonamides with trimethoprim. In the present investigation we found only 1 strain resistant to sulphonamides with trimethoprim (Table 2), and interestingly, this strain was also resistant to $\mathrm{O} / 129$. $\mathrm{O} / 129$ is a compound belonging to the pteridine group, not related to any of the other antimicrobial substances used in the present study.

In an investigation of the sensitivity of $259 \mathrm{~V}$. anguillarum strains to 12 antimicrobial agents, Aoki et al. (1981) found 9 strains sensitive to all drugs while the remaining were resistant to various combinations of the 6 antibacterial drugs, chloramphenicol, tetracycline, sulphonamides, nalidixic acid, furazolidone, and trimethoprim. Transferable $\mathbf{R}$ plasmids were detected in 165 of the 250 resistant strains, encoding resistance to combinations of chloramphenicol, tetracycline, and sulphonamides. All strains were sensitive to streptomycin, kanamycin, and aminobenzyl penicillin, and - interestingly - highly sensitive to colistin. The first colistin resistant $V$. anguillarum strain was found in Japan in 1980 (Aoki 1992) but the resistance could not be transferred to $E$. coli. In the present study we found that a large proportion of serogroup $\mathrm{O} 1$ 


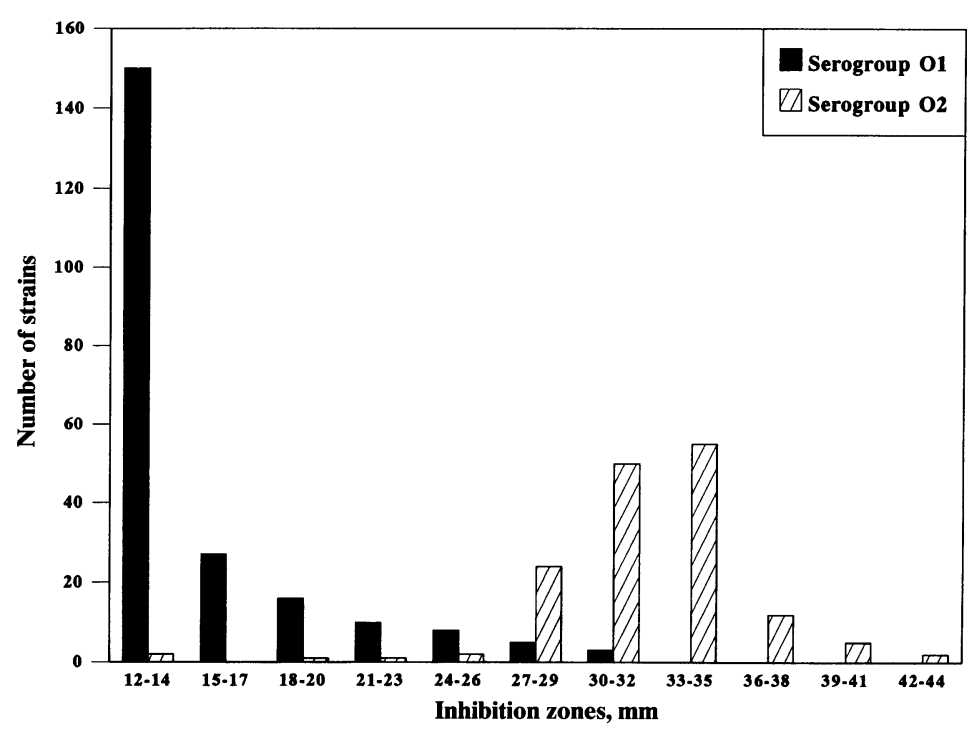

Figure 2. Inhibition zone diameters of Vibrio anguillarum serogroup $\mathrm{O} 1$ and $\mathrm{O} 2$ for colistin.

and $\mathrm{O} 3$ but not $\mathrm{O} 2$ carried natural resistance to colistin, irrespective of possible previous exposure to this agent. Several strains in our study carried large plasmids, comparable in size to the $\mathbf{R}$ plasmids described from Japan, but without showing resistance to any of the antibiotics tested to which $\mathrm{R}$ factors have previously been described. Likewise, some of the antibiotic resistant strains carried plasmids but with sizes far from those of the Japanese $\mathrm{R}$ plasmids. In our study we did not carry out experiments to investigate the transferability of the resistance. Further studies should be carried out to study the possible connection between antibiotic resistance and the various plasmids demonstrated in the experiments.

For most antibiotics, the strains tested were highly susceptible. The sizes recorded for the inhibition zones for these antibiotics were very large and never gave rise to problems with interpretation of results. However, for ampicillin, spiramycin, and lincomycin, a very large proportion of the strains displayed inhi- bition zones close to the break points, given by the manufacturer. According to Murray et al. (1992) the interpretation of results when zone diameters are close to break points is very critical due to the uncertainty of the disc diffusion method. Slight variations in diameters of inhibition zones are likely to occur upon repeated testing. In our study, results one $\mathrm{mm}$ from break points were always retested once or even twice. For ampicillin and lincomycin the reproducibility was very high, whereas spiramycin showed more variation. The disc diffusion method must therefore be considered unsuitable for testing of sensitivity of $V$. anguillarum to spiramycin. In contrast, the determination of MIC values on agar plates gave easily interpretable results.

\section{Acknowledgements}

The technical assistance of Miss Susanne Faaborg Nielsen and Miss Annette Rasmussen and the financial support from the Danish Agricultural and Veterinary Research Council, grant no. 13-4508-1 NMP and 13-4710-1, from the Nordic Council of Ministers, 
and from CEC contract number AIR-CT92-0341 is gratefully appreciated.

\section{References}

Alderman DJ, Michel C: Chemotherapy in aquaculture today. In: Michel $C \&$ Alderman DJ (eds.): Chemotherapy in aquaculture: from theory to reality. Off. Int. Epiz., Paris, France, 1992, pp. 324.

Alsina M, Martínez-Picado J, Jofre J, Blanch AR: A medium for presumptive identification of Vibrio anguillarum. Appl. environ. Microbiol. 1994, 60, 1681-1683.

Aoki T: Present and future problems concerning the development of resistance in aquaculture. In: Michel C\& Alderman DJ (eds.): Chemotherapy in aquaculture: from theory to reality. Off. Int. Epiz., Paris, France, 1992, pp. 254-262.

Aoki T, Egusa S, Arai T: Detection of $\mathrm{R}$ factors in naturally occurring Vibrio anguillarum strains. Antimicrob. Agents Chemother. 1974, 6, 534538.

Aoki T, Jo Y, Egusa S: Frequent occurrence of drug resistant bacteria in ayu (Plecoglossus altivelis) culture. Fish Pathol. 1980, 15, 1-6.

Aoki T, Kanazawa T, Kitao T: Epidemiological surveillance of drug resistant Vibrio anguillarum strains. Fish Pathol. 1985, 20, 199-208.

Aoki T, Kitao T, Kawano K: Changes in drug resistance of Vibrio anguillarum in cultured ayu, Plecoglossus altivelis Temminck and Schlegel, in Japan. J. Fish Dis. 1981, 4, 223-230.

Aoki T, Kitao T, Watanabe $S$, Takeshita S: Drug resistance and $\mathrm{R}$ plasmids in Vibrio anguillarum isolated in cultured ayu (Plecoglossus altivelis). Microbiol. Immunol. 1984, 28, 1-9.

Casals JB, Pringler N: Antibacterial/antifungal sensitivity testing using Neo-sensitabs. Rosco Diagnostica, Taastrup, Denmark, 1991.

Crosa JH, Schiewe MH, Falkow S: Evidence for plasmid contribution to virulence of the fish pathogen Vibrio anguillarum. Infect. Immun. 1977, 18, 509-513.

Davidson LS, Oliver JD: Plasmid carriage in Vibrio vulnificus and other lactose-fermenting marine vibrios. Appl. environ. Microbiol. 1986, 51, 211213.

Hansen PK, Lunestad BT, Samuelsen OB: Ecological effects of antibiotics and chemotherapeutics from fish farming. In: Michel $C \&$ Alderman $D J$ (eds.): Chemotherapy in aquaculture: from the- ory to reality. Off. Int. Epiz., Paris, France, 1992, pp. 174-178

Hedges RW, Smith P, Brazil G: Resistance plasmids of aeromonads. J. gen. Microbiol. 1985, 131, 2091-2095.

Hedges RW, Vialard JL, Pearson NJ, O'Grady F: R plasmids from Asian strains of Vibrio cholerae. Antimicrob. Agents Chemother. 1977, 11, 585588.

Heijden MHT van der, Muiswinkel WB van, Grondel $J L$, Boon JH: Immunomodulating effects of antibiotics. In: Michel $C \&$ Alderman DJ (eds.): Chemotherapy in aquaculture: from theory to reality. Off. Int. Epiz., Paris, France, 1992, pp. 219-230

Inglis V, Yimer E, Bacon EJ, Ferguson S: Plasmidmediated antibiotic resistance in Aeromonas salmonicida isolated from Atlantic salmon, Salmo salar L., in Scotland. J. Fish Dis. 1993, 16, 593-599.

Kado CI, Liu ST: Rapid procedure for detection and isolation of large and small plasmids. J. Bacteriol. 1981, 145, 1365-1373.

Larsen JL: Vibrio anguillarum: characterization, ecology, and patogenicity. Dissertation. DSR Press, Copenhagen, Denmark, 1990.

Larsen JL, Olsen JE: Occurrence of plasmids in Danish isolates of Vibrio anguillarum serovars $\mathrm{O} 1$ and $\mathrm{O} 2$ and association with phenotypic characteristics. Appl. environ. Microbiol. 1991, 57, 2158-2163.

Larsen JL, Pedersen K, Dalsgaard I: Vibrio anguillarum serovars associated with vibriosis in fish. $\mathrm{J}$. Fish Dis. 1994, 17, 259-267.

Lunestad BT: Fate and effects of antibacterial agents in aquatic environments. In: Michel $C \&$ Alderman $D J$ (eds.): Chemotherapy in aquaculture: from theory to reality. Off. Int. Epiz., Paris, France, 1992, pp. 152-161.

Macrina FL, Kopecko DJ, Jones KR, Ayers DJ, McCowen KR: A multiple plasmid-containing Escherichia coli strain: Convenient source of size reference plasmid molecules. Plasmid 1978, 1, 417-420.

Mitoma Y, Aoki T, Crosa JH: Phylogenetic relationships among Vibrio anguillarum plasmids. Plasmid 1984, 12, 143-148.

Muroga K, Yoneyama N, Jo Y: Vibriostatic agentnonsensitive Vibrio anguillarum isolated from ayu. Fish Pathol. 1979, 13, 159-162.

Murray PR, Zeitinger JR, Krogstad DJ: Reliability of disc diffusion susceptibility testing. Infection Control and Hospital Epidemiology 1992, 3, 230-237. 
Myhr E, Larsen JL, Lillehaug A, Gudding R, Heum $M$, Håstein T: Characterization of Vibrio anguillarum and closely related species isolated from farmed fish in Norway. Appl. environ. Microbiol. 1991, 57, 2750-2757.

Samuelsen $O B$ : The fate of antibiotics/chemotherapeutics in marine aquaculture sediments. In: Michel C\& Alderman DJ (eds.): Chemotherapy in aquaculture: from theory to reality. Off. Int. Epiz., Paris, France, 1992, pp. 162-173.

Sandaa $R-A$, Enger $\emptyset$ : Transfer of a broad range plasmid from Aeromonas salmonicida to bacteria indigenous to the marine environment. p. 31, Abstr. 6th Int. Conf. "Diseases of Fish and Shellfish", Brest, France, September 5-10, 1993.

Schlotfeldt HJ: Current practics of chemotherapy in fish culture. In: Michel $C \&$ Alderman DJ (eds.): Chemotherapy in aquaculture: from theory to reality. Off. Int. Epiz., Paris, France, 1992, pp. 25-38.

Sizemore RK, Colwell RR: Plasmids carried by antibiotic-resistant marine bacteria. Microb. Agents Chemother. 1977, 12, 373-382.

Sørensen UBS, Larsen JL: Serotyping of Vibrio anguillarum. Appl environ Microbiol 1986, 51, 593597.

Sørum H, Kvello JH, Håstein H: Occurrence and stability of plasmids in Aeromonas salmonicida ss salmonicida isolated from salmonids with furunculosis. Dis. aquat. Org. 1993, 16, 199-206.

Sørum H, Poppe T, Olsvik Ø: Plasmids in Vibrio salmonicida isolated from salmonids with hemorrhagic syndrome (Hitra disease). J. clin. Microbiol. 1988, 26, 1679-1683.

Tanaka M, Hanada H, Yoshikawa M: Vibriosis of ayu in Shizuoka Prefecture, from 1984 to 1990 serotype and drug sensitivity. Gyobyo Kenkyu 1993, 28, 77-82.

Threlfall EJ, Rowe B, Ferguson JL, Ward LR: Characterization of plasmids conferring resistance to gentamicin and apramycin in strains of Salmonella typhimurium phage type $204 \mathrm{C}$ isolated in Britain. J. Hyg. Camb. 1986, 97, 419-426.

Toranzo AE, Barja JL, Colwell RR, Hetrick FM: Characterization of plasmids in bacterial fish pathogens. Infect. Immun 1983a, 39, 184-192.
Toranzo AE, Barja JL, Potter SA, Colwell RR, Hetrick FM, Crosa JH: Molecular factors associated with virulence of marine vibrios isolated from striped bass in Chesapeake Bay. Infect. Immun 1983b, 39, 1220-1227.

Toranzo AE, Santos Y, Lemos ML, Ledo A, Bolinches J: Homology of Vibrio anguillarum strains causing epizootics in turbot, salmon and trout reared on the Atlantic coast of Spain. Aquaculture 1987, 67, 41-52.

Toranzo AE, Santos Y, Núñes $S$, Barja JL: Biochemical and serological characteristics, drug resistance and plasmid profiles of Spanish isolates of Aeromonas salmonicida. Gyobyo Kenkyu 1991, 26, 55-60.

Zhao J, Kim E, Kobayashi T, Aoki T: Drug resistance of Vibrio anguillarum isolated from ayu between 1989 and 1991. Nippon Suisan Gakkaishi 1992, 58, 1523-1527.

\section{Sammendrag}

Antibiotikaresistens hos Vibrio anguillarum sammenholdt med serotype og plasmid indhold.

I alt 520 Vibrio anguillarum stammer, hovedsagelig af europæisk oprindelse, isoleret fra fisk og fra miljøet, blev testet for følsomhed overfor 20 forskellige antibiotika. Resultaterne blev sammenholdt med data for serogruppe og plasmidindhold. Alle stammer var følsomme for neomycin, spectinomycin, nitrofurantoin, flumequin og oxolinsyre, mens flertallet af stammerne var følsomme for streptomycin, oxytetracyclin, chloramphenicol, sulfonamider, sulfonamider med trimethoprim, nalidixan, rifampicin, novobiocin og O/129. Størstedelen var resistente overfor makroliderne, spiramycin og lincomycin. For ampicillins, cephalothins og colistins vedkommende blev der iagttaget markante forskelle i følsomhed mellem de forskellige serogrupper. De fleste serogruppe $\mathrm{O} 1$ stammer var resistente overfor colistin og følsomme overfor ampicillin og cephalothin, mens det omvendte var tilfældet for $\mathrm{O} 2$ stammerne. Plasmider blev påvist hos såvel følsomme som resistente stammer, og tilstedeværelsen af bestemte plasmider kunne ikke associeres med antibiotikaresistens, men der blev ikke udført konjugations-

(Accepted October 13, 1994).

Reprints may be requested from: K. Pedersen, Dept. of Veterinary Microbiology, Laboratory of Fish Diseases, The Royal Veterinary and Agricultural University, Bülowsvej 13, DK-1870 Frederiksberg C, Denmark. 